\title{
Preparing for (and avoiding) the courtroom
}

\author{
Jeff Wolfson \& Russ Emerson \\ Intellectual property (IP) is often the most valued asset of biotech firms, especially startups. Two IP lawyers offer \\ guidance on avoiding suits altogether, when to settle them and when to fight.
}

$\mathrm{G}$ etting sued can be terrifying, especially for a small company. The best thing a firm can do is minimize the risk of ever reaching that point. In our experience, a few good practices along the way can not only increase your odds of winning if a full-blown trial occurs but also help you avoid the courtroom entirely.

\section{First principles-your business}

The first thing to do is to make sure you have suitable agreements in place with employees, consultants and related associates. Often what is at issue in court cases is not another company's patent infringement claims but rather a disgruntled employee's or consultant's claims of ownership of the invention or work product you thought the company owned. In our experience defending biopharmaceutical and other companies against these claims, we've learned that it's best to have well-drafted agreements in place at the outset of the relationship. Consultants have been a frequent source of IP ownership disputes, and certain key employees and managers can also present increased risk. For example, a consultant brought on board to help a company program one small part of a newly developed biosensing device could later allege she was a co-inventor and could license the entire technology to her own newly set-up company to compete. A well-drafted consulting agreement would require her to assign to the contracting company any invention or work product arising from her limited efforts to prepare the program as instructed and as funded by the company.

Jeff Wolfson and Russ Emerson are partners at Haynes and Boone, LLP (http://www. haynesboone.com/). Jeff Wolfson is located at 1615 L Street NW, Suite 800, Washington, DC 20036, USA. Russ Emerson is at 901 Main St., Suite 3100, Dallas, Texas 75202, USA. e-mail: jeff.wolfson@haynesboone.com or russ.emerson@haynesboone.com
Underlying the above scenario is an interesting feature of IP-multiple inventors or authors, or later assignees of the rights, are each free to license the IP rights to others without accounting for the profits. Only proper agreements can avoid this problem in the United States. These types of disputes have particularly been a concern for US corporations because, though much of the world vests an employer with automatic invention ownership, US law does so only in limited circumstances-and those circumstances do not include the use of consultants. To avoid disputes with ex-employees (or worse, current key employees) or ex-consultants, be sure to draft agreements for employees and consultants that do the following: require them to disclose and assign inventions to the company; outline noncompetition during and for a short period after association with the company; include nonsolicitation of company personnel and clients; and provide nondisclosure obligations restricting disparagement and publication of inventions.

Given the importance of showing ownership — especially exclusive ownership of IP —in raising capital and entering royalty-generating agreements, avoid using boilerplate employment and consultant agreements taken from the internet or drafting a 'super-short contract just to cover us'. The contract need not be book length, but stinting on content often means leaving out key provisions, and that won't help avoid an ownership dispute or favorably affect the outcome of a later dispute. At a minimum, including all the typical provisions of a well-drafted agreement should help minimize the disputed issues in an ownership contest, which usually reduces the cost and complexity of resolving such a dispute.

In our experience, individuals looking for employment or consulting work rarely reject reasonable provisions that protect a company's rights. But be sure the provisions are not too onerous - particularly concerning postemployment restrictions-as they may run afoul of state laws. Moreover, different types of employees or consultants often require carefully tailored provisions. For example, an agreement for a key employee hired to supervise $R \& D$ efforts should include additional provisions and restrictive language providing noncompete and nonsolicit provisions. (We have not addressed agreements with vendors, suppliers, partners and the like, but these are usually just as important.) Although we regularly provide counsel on such agreements, both in preparing agreements and reviewing the form agreements prepared by third parties, many treatises and articles provide an overview of common types of provisions and agreements. For example, the article "Minimizing the risks of litigation by contract," by P. D. Keating, available at our firm's website, discusses general provisions common to many business contracts.

\section{Patent protection}

After the employee and consultant contracts are in place, focus on patent protection. Recent US Supreme Court decisions, proposed US Patent and Trademark Office procedures and pending patent-reform legislation are all presenting threats to the scope and strength of patents, but for now, patent protection can cover various categories of biotech inventions (Box 1).

You should give careful strategic consideration to whether, when and exactly what to disclose in initial patent applications and potential follow-on filings. Also consider what information is included in publications, marketing materials and even press releases, as all of these can destroy patentability. And if you've been encouraged to slap a cover sheet on a presentation and file it as a provisional application before publication, don't do it. Typically, this isn't helpful. Laterfiled utility patent applications only get the 
benefit of the earlier, provisional filing date if the earlier one fully disclosed the details of the claimed invention. And recent case law requires the patent owner to prove the earlier priority rather than relying on the longstanding presumption of validity.

Despite the cost, you can avoid much aggravation (and potential loss of patent rights) by working with your in-house or external patent counsel to identify deadlines relating to publication or commercial product launch sufficiently ahead of time, thus preventing emergency patent filings. The best course of action is to treat the provisional filing efforts as a final application filing. Using the appropriate strategy, an invention can still be properly protected in certain circumstances, especially in the United States and possibly Canada, even when a poorly prepared provisional application was filed already.

Public disclosure of the invention - through either a presentation or commercial salesposes another risk. Public disclosure can cause an immediate loss of rights in many foreign countries. Sufficient delay in filing a patent application will ultimately render an invention nonpatentable even in the United States. Thus, every employee and consultant should be bound by confidentiality restrictions so that the company has some control over who makes disclosures and when they occur in connection with a filing for patent protection.

Ultimately, patent applications and patents may help resolve infringement suits by providing a bargaining chip for license or sale as part of a settlement or other adverse negotiations. In some cases, the party bringing suit is a competitor who in turn is infringing your patent rights, creating the possibility for cross-licensing. But you must take care in preparing any licenses or you can wind up in a licensing dispute instead of a patent infringement dispute or even a suit based on both patent infringement and breach of contract over a failed license.

\section{Watching me, watching you}

Another thing to consider is: Are you keeping an eye on your competitors? You should be, because they're watching you. Some companies are large enough to have their own employees monitor competitors for product or service releases and patent filings. In some cases, every competitor product is purchased and warehoused for use in later patent disputes or for analysis of features that may be adopted to help make their own products a success. We often search the patent publications and patents issuing to a client's chief competitors or potential competitors. These searches can identify potential infringement of competitor patent rights, pinpoint theft of trade secrets by former employees, as well as determine when a competitor is about to launch products in your most profitable business line. Detecting problems early can provide enough time for responsive tactics, including designing products around a competitor's patent rights, obtaining opinion of counsel on a patent's invalidity and improving your products or marketing ahead of a competitor's product launch.

Besides your competitors, are you also watching yourself? It's worthwhile to consider asking an independent patent lawyer to conduct a 'peer review' of some or all of your patent portfolio to identify fatal flaws, gaps and weaknesses in the scope, strength and ownership of your patent protection. In our experience, audits can identify these and other issues, such as unneeded duplicative patent protection or areas for further filings or R\&D. These audits also can be conducted with an eye toward actual or proposed products to help ensure that the patent protection being sought matches the products' commercial value. Sometimes, broad inventions covered by a well-drafted patent can be licensed even outside the owner's field of business. One example is a new platform technology involving polymeric blends and structures for controlled-release delivery of biologic drugs, which when claimed properly can cover the blends and structures for use in a variety of

\section{Box 1 Patentable biotech inventions}

There are several types of inventions that can be patented. We list the most common below:

- Compounds (peptides, proteins, antigens, monoclonal antibodies, small molecules, nucleic acid moieties, polymers, hydrate forms, polymorphic forms, enantiomers, etc.)

- Biologic compositions, such as vaccines, including the compounds listed above with a carrier

- Articles of manufacture (drug-delivery devices, prosthetics, implants, etc.)

- Methods of synthesizing the compounds and compositions, or methods of making the articles listed above

- Methods of treating or preventing one or more diseases or conditions, or methods of using the compounds, compositions or articles listed above

applications outside of delivering the company's core drug formulation(s). This permits patent cost recovery and revenue generation through a royalty stream that doesn't involve licensing to a competitor, because licensing outside the main field of business is done through noncompetitors. Human Genome Sciences (Rockville, Maryland), for example, is using a similar model relating to its proprietary genomic information to generate revenue by offering drug candidates for out-licensing (http://www.hgsi.com/ partnerships/licensing-opportunities.html).

Competitive intelligence can help create new strategies and improve execution of business plans in various ways, from catching employee poaching and eliminating duplicative research to avoiding legitimate third-party patent rights. If you plan to launch a new product, we recommend evaluating the risk of its infringing on other patents, which may involve conducting full clearance searching (also called 'freedomto-operate searching'), having a registered patent lawyer prepare an opinion, if appropriate, and even modifying a product design to further avoid a competitor's possible legitimate patent claims. Given the tremendous expense of developing many biopharma products, preliminary evaluations can be conducted periodically during product development, rather than at the actual product launch. But this early clearance searching and evaluation must be updated near the product launch to check for new thirdparty (and especially competitor) patent rights and to consider any changed product specifications. Although clearance analyses and opinion drafting can be expensive, our clients have found that spending a few tens of thousands of dollars or more to clear a potentially lucrative product before launch can greatly minimize the risk of a patent infringement lawsuit-or worse, a preliminary injunction that requires pulling the new product off the market entirely. And even if a suit is not avoided, some can be quickly resolved if the proper clearance and evaluation were conducted on the new product during R\&D.

It may seem costly to implement some of these preventive tactics, but we've never seen a client wish they had done less to minimize the risk of a patent infringement suit or to study the issues at stake in these disputes. If the best practices described above do nothing more than minimize the issues in contention in one suit, the preventive cost will often be recovered.

\section{Danger at the gate}

If it's already too late-if you've already picked up the phone and heard these three little words: "We've been sued"- then it's time to set about limiting the damage. The median cost of patent litigation when between $\$ 1$ and $\$ 25$ million are 
at stake is more than $\$ 2.6$ million. That is a lot of money for any company, but it is especially burdensome for a small biotech. Therefore, it is crucial that you spend your dollars wisely by investing in case analysis as soon as possible to maximize a positive settlement outcome. After all, $\sim 95 \%$ of patent infringement cases settle before trial.

When sued for patent infringement, it is important to quickly contact and retain counsel that is experienced in litigating patent cases. If you have regular patent prosecution counsel, he or she probably will have recommendations for patent litigation counsel. It is important that a patent litigator be involved in evaluating the case as soon as possible because patent prosecutors and patent litigators see the world through different lenses. Prosecutors generally help their clients acquire patent rights, negotiate and prepare agreements, license patent rights and evaluate noninfringement and invalidity issues in advance. Litigators generally help their clients defend their patent rights or defend against infringement claims. As with an independent peer review of a patent portfolio by a patent prosecutor as noted above, a litigator will often spot weaknesses that have not yet come to light or that cannot be uncovered until some discovery occurs.

Once you have retained patent litigation counsel, the first and most critical task is to evaluate the infringement claims (Box 2).

Litigation counsel should also begin exploring invalidity defenses. At the very least, knowledgeable company employees should be asked about the state of the technology relating to the asserted patents and about prior art (patents, products, publications and commercial use) that can invalidate the asserted patent(s). An external prior art search relating to all of the patents asserted should typically be ordered to consider additional possible invalidity issues.

You should also think about hiring, early on, a technical expert to assist in these analyses. The goal is to determine the likelihood that the infringement accusations have any merit and whether the asserted patents can successfully be invalidated.

Next, it's worth exploring whether you can attack with a patent infringement counterclaim of your own. It is likely that your company owns a number of patents, particularly if the recommendations above have been pursued. If your accuser is a competitor, you may be able to counterclaim for infringement of your own patent rights, which can be leveraged for an early and effective settlement. If your competitor has larger sales or profit numbers, they have more at stake if each of you is infringing the other party's patent rights.

\section{Box 2 Steps to evaluate infringement claims}

Detailed analysis of infringement claims is vital to assess liability when litigating patent cases. In most cases, the main aspects of such an evaluation are the following:

- Review and analyze the patent(s) asserted, as well as their prosecution histories (the public record of the proceedings before the US Patent and Trademark Office leading to the patent's issuance)

- Construe the claims

- Compare the claims to the accused products or methods

- Gather and review critical documents

- Interview witnesses who are likely to have information relating to the design and operation of the accused technology

Finally, your company should explore the possibility of developing a 'design-around' that will allow you to produce the accused product or use the process without infringing the asserted patents. Of course, if you took that preventative step noted above and obtained a full freedomto-operate search and analysis, you probably aren't actually infringing any patents that were uncovered at the time. But it may be possible to minimize damages or risks by moving a product further away from claims asserted against your product(s).

\section{Calculating damage}

Once you determine the likelihood of infringement, you should determine what the damages may be if your company is found to have infringed. Successful patent infringement plaintiffs may recover at least a reasonable royalty for the unauthorized practice of their patented inventions. We have helped determine common patent royalty rates in the biotech industry to allow companies to consider the potential downside of losing a patent infringement trial.

If the patentee practices the inventions claimed in its patents, however, the company might be entitled to recover its lost profits, or the profits that it could have realized but for the alleged infringement.

Another issue that you must consider is the likelihood of a court enjoining infringement. If you are sued by a 'nonpracticing entity' or 'patent troll', they will not be entitled to lost-profits damages or, in most cases, an injunction under recent court decisions. Again, in addition to engaging a technical expert on infringement and validity issues, it may be wise to engage a damages expert, via your patent litigation counsel, early on to determine your company's possible damages exposure.

Using the technical infringement and invalidity analysis described above, along with the exposure analysis, your team can estimate an 'expected value' of the infringement case.
This early analysis may sound (and, indeed, be) expensive. But the fees will be a small fraction of the cost of defending a patent infringement case through trial, not to mention the economic and publicity costs of a negative outcome at trial. And it is money well spent, because it naturally allows your company to develop a more informed and effective settlement strategy; and, if the case does not settle, this early work will prove useful in developing a focused litigation strategy.

When considering settlement, take into account the following factors: the likelihood of infringement; the feasibility of a successful invalidity defense; the expected damages exposure; the probability of injunctive relief; the possibility of developing a 'design-around'; whether you can assert any counterclaims; the cost of litigation; and your company's (and your opponent's) business objectives.

The final factor is the most important, so it's crucial to include in the discussion executives familiar with your company's business and IP strategy, the industry's competitive climate and the importance of the accused products or processes to your company's success.

Once you have developed a settlement strategy, and if you believe that an early settlement is wise, we recommend initiating settlement discussions as soon as you are in a position to do so. Some believe that discussing settlement early, especially if initiated by the defendant, is a sign of weakness. Nonsense. Savvy players know that most cases settle, and most cases should settle. By following the pre- and postfiling recommendations above, your company can put itself in a good position to successfully and effectively settle the case and thus spend its efforts on more productive matters such as running a thriving business and generating life-saving medicines.

\section{ACKNOWLEDGMENT}

This article is for informational purposes only and is not intended to be legal advice or create an attorneyclient relationship. The opinions expressed herein are the opinions of the authors only and do not necessarily reflect the opinions of Haynes and Boone, LLP. 